\author{
A. SAVYCH ${ }^{1}$, S. MARCHYSHYN ${ }^{1}$, O. DOROSHENKO ${ }^{2}$ \\ ${ }^{1}$ I. Horbachevsky Ternopil National Medical University, Ukraine \\ ${ }^{2}$ Ivano-Frankivsk National Medical University, Ukraine
}

\title{
SCREENING OF HYPOGLYCEMIC ACTIVITY OF HERBAL MIXTURES (MESSAGE II)
}

Topicality. Diabetes mellitus is an important social and medical problem, as it causes the development of dangerous complications that lead to disability and mortality. This disease is characterized by a multi-vector pathogenesis that requires a comprehensive approach to treatment. Due to the use of mixtures of medicinal plants in the treatment of diabetes, it is possible to cover all aspects of the development of this disease and its complications. In addition, the niche of the pharmaceutical market of Ukraine with phytomixtures is almost empty.

Aim. To study the hypoglycemic activity of the herbal mixtures, which are used in folk medicine for diabetes mellitus type 2 prevention and treatment, but do not have a scientific basis and to establish their conditional therapeutic dose.

Materials and methods. The study has been performed in male albino rats weighing 180-200 g, during 20 days they have been receiving orally for preventive treatment aqueous extracts (1:10) of the studied herbal mixtures at a dose $6 \mathrm{~mL} / \mathrm{kg} /$ day, $9 \mathrm{~mL} / \mathrm{kg} /$ day and $12 \mathrm{~mL} / \mathrm{kg} /$ day and comparison drugs - the official herbal mixtures "Arfazetin" at a dose $9 \mathrm{~mL} / \mathrm{kg} /$ day and tablets metformin at a dose $60 \mathrm{mg} / \mathrm{kg} /$ day. The study of hypoglycemic properties and the establishment of a conditional therapeutic dose of the studied mixtures was carried out using glucose loading tests. All experiments have been performed in accordance with general ethical principles with the recommendations of the EEC Council directive 2010/63/EU about the protection of animals used for scientific experiment.

Results and discussion. The results of the study showed the 20-day preventive treatment by the herbal mixtures reduced alimentary hyperglycemia at the 30th minutes of OGTT and helped regulate carbohydrate tolerance disorders by reducing hyperglycemia at the 15th minutes of IPGTT. The highest hypoglycemic activity showed the herbal mixture No. 7 in a dose $12 \mathrm{~mL} / \mathrm{kg} /$ day, which was almost on a par with the comparison drug - tablets metformin, but exceeded the official herbal mixture "Arfazetin". In addition, the dose-dependence of the effectiveness of all five studied herbal mixtures was established.

Conclusions. For the first time, it was conducted the screening study of hypoglycemic activity of the herbal mixtures, which are used in folk medicine for the prevention and treatment of diabetes mellitus type 2. It was determined that the greatest effectiveness in terms of the ability to reduce alimentary hyperglycemia during OGTT and reduce impaired carbohydrate tolerance during IPGTT show the herbal mixture No. 7, which includes Inulae rhizomata et radices, Helichrysi arenarii flores, Maydis style cum sigmatis, Origani herba, Rosae fructus, Taraxaci radices. It was established its conditional therapeutic dose $12 \mathrm{~mL} / \mathrm{kg} /$ day.

Key words: herbal mixtures; hypoglycemic activity; diabetes mellitus

\section{А. О. Савич ${ }^{1}$, С. М. Марчишин ${ }^{1}$, О. Г. Дорошенко ${ }^{2}$}

${ }^{1}$ Тернопільський національний медичний університет імені І. Я. Горбачевського моз України

${ }^{2}$ Івано-Франківський національний медичний університет, Україна

\section{Скринінгове дослідження гіпоглікемічної активності рослинних зборів (повідомлення II)}

Актуальність. Цукровий діабет є важливою соціальною та медичною проблемою, адже спричиняє розвиток небезпечних ускладнень, що призводять до інвалідизації та смертності населення. Це захворювання характеризується багатовекторним патогенезом, що потребує комплексного підходу до лікування. Завдяки застосуванню зборів лікарських рослин у терапії цукрового діабету можна охопити усі ланки розвитку даного захворювання та його ускладнень. Окрім цього ніша фармацевтичного ринку України з фітозборів практично порожня.

Метою даного дослідження стало вивчення гіпоглікемічних властивостей рослинних зборів, що використовуються у народній медицині для профілактики та лікування цукрового діабету 2 типу та встановлення їх умовно терапевтичної дози.

Матеріали та методи. Дослідження проводилися на інтактних нормоглікемічних білих щурах самцях масою 180-200 г, які з метою профілактичного лікування впродовж 20-ти днів перорально отримували водні екстракти (1:10) досліджуваних зборів у дозі 6 мл/кг/день, 9 мл/кг/день та 12 мл/кг/день та препарати порівняння - офіцинальний збір «Арфазетин» у дозі 9 мл/кг/день і таблетки метформіну у дозі 60 мг/кг/день. Вивчення гіпоглікемічних властивостей та встановлення умовно терапевтичної дози досліджуваних засобів здійснювали за допомогою тестів глюкозного навантаження. Усі досліди виконували з дотриманням загальних етичних принципів згідно з рекомендаціями Директиви ЄC 2010/63/EU про захист використовуваних тварин для наукових цілей.

Результати та їх обговорення. Результати дослідження показали, що 20-ти денне профілактичне введення рослинних зборів знижувало аліментарну гіперглікемію на 30-й хв ОТТГ та сприяло зменшенню порушень толерантності до вуглеводів шляхом зниження гіперглікемії на 15-й хв ВОТТГ. Найбільшу гіпоглікемічну активність проявив рослинний збір № 7 у дозі 12 мл/кг/день, яка була практично на рівні з препаратом порівняння таблетками метформіну, але перевищувала за ефективністю офіцинальний збір «Арфазетин». Окрім цього було встановлено дозозалежність ефективності усіх п’яти досліджуваних рослинних зборів. 
Висновки. Вперше проведено скринінгове дослідження гіпоглікемічної активності рослинних зборів, що застосовуються в народній медицині для профілактики та лікування цукрового діабету 2 типу. Визначено, що найбільшу ефективність за здатністю знижувати аліментарну гіперглікемію під час ОТТГ та знижувати порушення толерантності до вуглеводів під час ВОТТГ проявив рослинний збір № 7 (до складу якого входять оману кореневища з коренями, цмину квітки, кукурудзи стовпчики з приймочками, материнки трава, шипшини плоди, кульбаби корені). Встановлено його умовно терапевтичну дозу, яка складає 12 мл/кг/день.

Ключові слова: рослинні збори; гіпоглікемічна активність; цукровий діабет

\section{А. А. Савич ${ }^{1}$, С. М. Марчишин ${ }^{1}$, О. Г. Дорошенко ${ }^{2}$}

${ }^{1}$ Тернопольский национальный медицинский университет имени И. Я. Горбачевского МЗ Украины

${ }^{2}$ Ивано-Франковский национальный медицинский университет, Украина

\section{Скрининговое исследование гипогликемической активности растительных сборов (сообщение II)}

Актуальность. Сахарный диабет является важной социальной и медицинской проблемой, поскольку приводит к развитию опасных осложнений, приводящих к инвалидизации и смертности населения. Это заболевание характеризуется многовекторным патогенезом и требует комплексного подхода к лечению. Благодаря применению сборов лекарственных растений в терапии сахарного диабета можно охватить все звенья развития данного заболевания и его осложнений. Кроме этого ниша фармацевтического рынка Украины по фитосборах практически пуста.

Цель. Изучение гипогликемических свойств растительных сборов, используемых в народной медицине для профилактики и лечения сахарного диабета 2 типа, и установление их условно терапевтической дозы.

Материалы и методы. Исследования проводились на интактных нормогликемических белых крысах самцах массой 180-200 г, которые с целью профилактического лечения в течение 20-ти дней перорально получали водные экстракты (1:10) исследуемых сборов в дозе 6 мл/кг/день, 9 мл/кг/день и 12 мл/кг/день и препараты сравнения - официнальный сбор «Арфазетин» в дозе 9 мл/кг/день, а также таблетки метформина в дозе 60 мг/кг/день. Изучение гипогликемических свойств и установление условно терапевтической дозы исследуемых средств осуществляли с помощью тестов глюкозной нагрузки. Все опыты проводили с соблюдением общих этических принципов согласно рекомендациям Директивы EC 2010/63/EU о защите используемых животных для научных целей.

Результаты и их обсуждение. Результаты исследования показали, что 20-дневное профилактическое использование растительных сборов снижало алиментарную гипергликемию на 30-й минуте ОТТГ и способствовало уменьшению нарушений толерантности к углеводам путем снижения гипергликемии на 15-й минуте ВЧТТГ. Наибольшую гипогликемическую активность проявил растительный сбор № 7 в дозе 12 мл/кг/день, которая была практически на уровне с препаратом сравнения - таблетками метформина, но превышала по эффективности официнальный сбор «Арфазетин». Кроме того, была установлена дозозависимость эффективности всех пяти исследуемых растительных сборов.

Выводы. Впервые было проведено скрининговое исследование гипогликемической активности растительных сборов, применяемых в народной медицине для профилактики и лечения сахарного диабета 2 типа. Определено, что наибольшую эффективность по способности снижать алиментарную гипергликемию при ОТТГ и снижать нарушение толерантности к углеводам при ВЧТТГ проявляет растительный сбор № 7 (в состав которого входят девясила корневища с корнями, бессмертника цветки, кукурузы рыльца, душицы трава, шиповника плоды, одуванчика корни). Установлено его условно терапевтическую дозу, которая составляет 12 мл/кг/день.

Ключевые слова: растительные сборы; гипогликемическая активность; сахарный диабет

\section{INTRODUCTION}

Diabetes mellitus is a global social problem in the field of health care, due to rapid spread of this disease and the development of serious complications such as microand macroangiopathies, which significantly reduce the quality and life expectancy of patients [1]. According to the official information of International Diabetes Federation (2019), the number of patients is projected to increase to 642 million by 2040 [2].

An important problem of pharmacovigilance is that existing pharmacotherapy can effectively reduce hyperglycemia, but it is not always able to stabilize fluctuations zn glycemic values during the day and maintain it at an optimal level. This leads to the formation of a cascade of pathological processes - excessive glycation and inactivation of the body's antioxidant defense system, triggering the processes of free radical oxidation of lipids and, as a consequently, the development of oxidative stress, which leads to the development and progression of diabetic angiopathies [1, 3, 4].

Therefore, the optimization of pharmacotherapy, search and study of new drugs with hypoglycemic activity for the prevention and treatment of this disease and its dangerous complications is a topical issue of pharmacy and medicine.

Phytotherapy is one of such an important fields, as it has a number of advantages over traditional therapy with using oral synthetic agents, namely, it is low-toxic, has a mild pharmacological effect and can be used for long periods without significant side effects, is well combined with synthetic drugs, has a complex activity through a number of biologically active compounds $[5,6]$. The combination of different medicinal plants is worth a particular attention, because such herbal mixtures will have more biologically active substances and will influence on the all links of the pathogenetic mechanism of development of 
diabetes mellitus and its complications $[7,8,9]$. In addition, the pharmaceutical market of Ukraine is represented mainly by synthetic antidiabetic drugs, which account for over $92 \%$ of all oral antidiabetic drugs. Today in Ukraine there are two antidiabetic herbal mixtures - the herbal mixture "Arfazetin", which includes Vaccinii myrtilli cormus, Phaseoli valvae fructum, Eleutherococci senticosi rhizomata et radices, Rosae fructus, Equiseti arvensis herba, Hyperici herba, Matricariae flores and - the herbal mixture "Sadifit", which includes Helianthi tubera, Steviae folia, Vaccini myrtilli cormus, Phaseoli valvae fructum, Thea chinensis, Menthae piperitae folia.

However, Vaccinii myrtilli cormus, Eleutherococci senticosi rhizomata et radices and Hyperici herba are potent plants that can be dangerous with prolonged use. In addition, Eleutherococci senticosi rhizomata et radices have a tonic effect and are contraindicated in coronary heart disease, heart failure and hypertension, which are often complications of diabetes.

The aim is to study the hypoglycemic activity of the herbal mixtures used in folk medicine for the prevention and treatment of diabetes mellitus type 2 [10], but do not have a scientific basis and to establish their conditional therapeutic dose.

\section{MATERIALS AND METHODS}

The herbal raw materials harvested in June to August 2019 in Ternopil region (Ukraine) were used. After harvesting, the raw materials were dried, crushed and brought back to standard according to the general GACP requirements [11]. The plants were identified by Department of Pharmacognosy with Medical Botany, I.Horbachevsky Ternopil National Medical University, Ternopil, Ukraine. The voucher specimens of the herbal raw materials have been deposited in Departmental Herbarium for future record.

For the study were used the five different herbal mixtures, which are used in folk medicine for the prevention and treatment of diabetes mellitus type 2 in Ukraine [10]. Composition of the mixtures is given in Tab. 1 .

The samples of the herbal raw material were grinded into a powder by laboratory mill. Then $10 \mathrm{~g}$ of each pow-

dered herbal mixture was put into a $100 \mathrm{~mL}$ conical flask and $120 \mathrm{~mL}$ of distilled water was added to each. The aqueous extracts were obtained by heating in the boiling water bath for $30 \mathrm{~min}$. The extracts were filtered using Whatmann filter paper No. 1. Then the filtrates were evaporated by rotary evaporator and were lyophilized to dryness. The lyophilized powders of each herbal mixture were stored at $4{ }^{\circ} \mathrm{C}$ for further use.

The aqueous extract of the comparison preparation the official herbal mixture "Arfazetin" was prepared using $5 \mathrm{~g}$ of dry raw material and $110 \mathrm{~mL}$ of distilled water (as indicated in the instructions for use) under the same conditions.

To prepare the metformin suspension, the metformin tablets were crushed and mixed with $2 \mathrm{~mL}$ of distilled water.
Table 1

\section{COMPOSITION OF THE HERBAL MIXTURES}

\begin{tabular}{|c|c|c|}
\hline $\begin{array}{c}\text { Herbal } \\
\text { mixtures }\end{array}$ & Herbals & $\begin{array}{l}\text { Quantity of the } \\
\text { herbals in the } \\
\text { mixtures, g }\end{array}$ \\
\hline No. 6 & $\begin{array}{l}\text { Avenae sativae semina } \\
\text { Cichorii radices } \\
\text { Elymi repens rhizomata } \\
\text { Rosae fructus } \\
\text { Pulmonaria radices }\end{array}$ & $\begin{array}{l}26.32 \\
26.32 \\
15.79 \\
21.05 \\
10.52 \\
\end{array}$ \\
\hline \multicolumn{3}{|c|}{ Total: 100.00} \\
\hline No. 7 & $\begin{array}{l}\text { Inulae rhizomata et radices } \\
\text { Helichrysi arenarii flores } \\
\text { Maydis style cum sigmatis } \\
\text { Origani herba } \\
\text { Rosae fructus } \\
\text { Taraxaci radices }\end{array}$ & $\begin{array}{l}10.00 \\
20.00 \\
20.00 \\
20.00 \\
20.00 \\
10.00\end{array}$ \\
\hline \multicolumn{3}{|c|}{ Total: 100.00} \\
\hline No. 8 & $\begin{array}{l}\text { Elymi repens rhizomata } \\
\text { Cichorii radices } \\
\text { Rosae fructus } \\
\text { Leonuri herba } \\
\text { Crataegi fructus }\end{array}$ & $\begin{array}{l}26.32 \\
26.32 \\
21.05 \\
15.79 \\
10.52 \\
\end{array}$ \\
\hline \multicolumn{3}{|c|}{ Total: 100.00} \\
\hline No. 9 & $\begin{array}{l}\text { Cichorii radices } \\
\text { Sophorae japonicae fructus } \\
\text { Urticae folia } \\
\text { Crataegi fructus } \\
\text { Polemonii rhizomata cum } \\
\text { radicibus } \\
\text { Melissae folia }\end{array}$ & $\begin{array}{l}44.44 \\
11.11 \\
11.11 \\
11.11 \\
11.11 \\
11.11\end{array}$ \\
\hline \multicolumn{3}{|c|}{ Total: 100.00} \\
\hline No. 10 & $\begin{array}{l}\text { Helianthi tuberosi tuber } \\
\text { Rosae fructus } \\
\text { Menthae folia } \\
\text { Elymi repens rhizomata } \\
\text { Polemonii rhizomata cum } \\
\text { radicibus } \\
\text { Crataegi fructus } \\
\end{array}$ & $\begin{array}{c}36.36 \\
18.18 \\
9.09 \\
9.09 \\
9.09 \\
18.18\end{array}$ \\
\hline
\end{tabular}

The official herbal mixture "Arfazetin" was purchased from PJSC Pharmaceutical Factory "Viola" (Ukraine), the standard drug - metformin SANDOZ $®$ from Lek S.A. (Poland).

The study was performed in male albino rats weighing between $180 \mathrm{~g}$ and $200 \mathrm{~g}$, which were bred at the animal house of the Central Research Laboratory of I. Horbachevsky Ternopil National Medical University, where they were kept under appropriate conditions (at a constant room temperature of $22 \pm 1{ }^{\circ} \mathrm{C}, 40-70 \%$ humidity conditions and a 12-hour light/dark cycle). Throughout the experimental period, the animals received standard rat diet and water ad libitum. The animals were treated in accordance with the internationally accepted standard ethical guidelines for laboratory animal use and care as described in the European Community Guidelines [12]. All protocols for animals experiment were approved by the animal ethical committee of I. Horbachevsky Ternopil National Medical University. 


\section{HYPOGLYCEMIC EFFECT OF THE HERBAL MIXTURES COMPARED TO THE OFFICIAL HERBAL MIXTURE “ARFAZETIN" AND TABLETS METFORMIN BY OGTT AFTER 20 DAYS OF PREVENTIVE TREATMENT OF NORMOGLYCEMIC RATS}

\begin{tabular}{|c|c|c|c|c|}
\hline \multirow{2}{*}{ Group of animals } & \multicolumn{4}{|c|}{ Glucose level, $\mathrm{mmol} / \mathrm{L}$} \\
\hline & $0 \min$ & $30 \mathrm{~min}$ & $60 \mathrm{~min}$ & $120 \mathrm{~min}$ \\
\hline \multicolumn{5}{|c|}{ Series second } \\
\hline Control & $4.17 \pm 0.07$ & $7.89 \pm 0.09$ & $7.62 \pm 0.12$ & $5.85 \pm 0.13$ \\
\hline HM “Arfazetin”, 9 mL/kg & $4.08 \pm 0.08$ & $5.38 \pm 0.11^{*}$ & $5.33 \pm 0.15^{*}$ & $4.92 \pm 0.14^{*}$ \\
\hline MET, $60 \mathrm{mg} / \mathrm{kg}$ & $3.91 \pm 0.16$ & $4.28 \pm 0.17 * / * *$ & $4.17 \pm 0.18^{*} / * *$ & $4.02 \pm 0.14^{*} / * *$ \\
\hline HM No. $6,6 \mathrm{~mL} / \mathrm{kg}$ & $4.12 \pm 0.12$ & $5.53 \pm 0.17^{*}$ & $5.42 \pm 0.18^{*}$ & $5.25 \pm 0.11^{*}$ \\
\hline HM No. $6,9 \mathrm{~mL} / \mathrm{kg}$ & $4.09 \pm 0.19$ & $5.62 \pm 0.15^{*}$ & $5.37 \pm 0.17 *$ & $5.22 \pm 0.14^{*}$ \\
\hline HM No. $6,12 \mathrm{~mL} / \mathrm{kg}$ & $3.95 \pm 0.17$ & $5.54 \pm 0.12^{*}$ & $5.41 \pm 0.15^{*}$ & $5.21 \pm 0.11^{*}$ \\
\hline HM No. $7,6 \mathrm{~mL} / \mathrm{kg}$ & $4.11 \pm 0.16$ & $5.53 \pm 0.11^{*}$ & $5.42 \pm 0.18^{*}$ & $5.24 \pm 0.18^{*}$ \\
\hline HM No. 7, $9 \mathrm{~mL} / \mathrm{kg}$ & $4.09 \pm 0.13$ & $5.41 \pm 0.18^{*}$ & $5.21 \pm 0.17 *$ & $5.04 \pm 0.19^{*}$ \\
\hline HM No. 7, $12 \mathrm{~mL} / \mathrm{kg}$ & $4.07 \pm 0.11$ & $4.42 \pm 0.17 * / * *$ & $4.31 \pm 0.13^{*} / * *$ & $4.12 \pm 0.14^{*}$ \\
\hline HM No. $8,6 \mathrm{~mL} / \mathrm{kg}$ & $4.13 \pm 0.13$ & $5.64 \pm 0.14^{*}$ & $5.37 \pm 0.18^{*}$ & $5.22 \pm 0.11^{*}$ \\
\hline HM No. $8,9 \mathrm{~mL} / \mathrm{kg}$ & $4.04 \pm 0.15$ & $5.61 \pm 0.11^{*}$ & $5.32 \pm 0.18^{*}$ & $5.21 \pm 0.17^{*}$ \\
\hline HM No. $8,12 \mathrm{~mL} / \mathrm{kg}$ & $4.32 \pm 0.18$ & $5.57 \pm 0.09 *$ & $5.38 \pm 0.17^{*}$ & $5.11 \pm 0.18^{*}$ \\
\hline HM No. 9, $6 \mathrm{~mL} / \mathrm{kg}$ & $4.21 \pm 0.16$ & $5.64 \pm 0.18^{*}$ & $5.51 \pm 0.16^{*}$ & $5.32 \pm 0.11^{*}$ \\
\hline HM No. 9, $9 \mathrm{~mL} / \mathrm{kg}$ & $4.17 \pm 0.18$ & $5.61 \pm 0.11^{*}$ & $5.43 \pm 0.14^{*}$ & $5.25 \pm 0.18^{*}$ \\
\hline HM No. $9,12 \mathrm{~mL} / \mathrm{kg}$ & $4.08 \pm 0.17$ & $5.52 \pm 0.18^{*}$ & $5.37 \pm 0.11 *$ & $5.21 \pm 0.19^{*}$ \\
\hline HM No. $10,6 \mathrm{~mL} / \mathrm{kg}$ & $4.11 \pm 0.18$ & $5.71 \pm 0.13^{*}$ & $5.52 \pm 0.18^{*}$ & $5.23 \pm 0.15^{*}$ \\
\hline HM No. $10,9 \mathrm{~mL} / \mathrm{kg}$ & $4.06 \pm 0.13$ & $5.53 \pm 0.18^{*}$ & $5.38 \pm 0.16^{*}$ & $5.21 \pm 0.14^{*}$ \\
\hline HM No.10, $12 \mathrm{~mL} / \mathrm{kg}$ & $4.09 \pm 0.17$ & $5.48 \pm 0.16^{*}$ & $5.38 \pm 0.14^{*}$ & $5.19 \pm 0.17^{*}$ \\
\hline
\end{tabular}

Notes: Values are expressed as mean \pm SEM from 8 rats; ${ }^{*} p<0.05$ with respect to Control group; ${ }^{* *}$ $p<0.05$ with respect to the herbal mixture "Arfazetin".

Screening study of hypoglycemic activity of the herbal mixtures and determination of their conditionally therapeutic dose was performed on intact normoglycemic rats. Animals were randomly divided into eight groups of eight animals $(n=8)$ each and received different preventive treatment once daily during 20 days. Group I (Control) received per os (p.o.) distilled water $(12 \mathrm{~mL} / \mathrm{kg} /$ day $)$, group II (HM "Arfazetin") - aqueous extract of the official herbal mixture "Arfazetin" (9 mL/kg/day, p.o.) [13], group III (MET) - suspension of metformin (60 mg/kg/day, p.o.) [14], group IV-VIII (HM) - aqueous extracts of the studied herbal mixtures No. $1-5$ in doses $6 \mathrm{~mL} / \mathrm{kg} /$ day, $9 \mathrm{~mL} / \mathrm{kg} /$ day and $12 \mathrm{~mL} / \mathrm{kg} /$ day, p.o. The last oral administration of the researched means was carried out 2 hours before the glucose load tests.

Fasting blood glucose (basal glycemia) was measured in tail blood samples after a 6-hour fast on 20th day of the experiment using a glucose analyzer (glucometer Accuk-Check, Germany). Oral Glucose Tolerance Test (OGTT) was performed after measuring basal glycemia by administering glucose solution $(3 \mathrm{~g} / \mathrm{kg}, p . o)$. Blood glucose levels were determined at $0,30,60$ and 120 minutes after glucose loading [15].

Measurements of the intraperitoneal glucose tolerance test (IPGTT) were performed on the 21st day of the experiment after overnight fasting (16-18 hours) by intraperitoneal administration of glucose solution $(2 \mathrm{~g} / \mathrm{kg}$, i. p.) to rats in the morning. The level of glucose in the blood obtained from the tail vein of animals was determined before the introduction of glucose and after 15, 45 and 60 minutes using a glucose analyzer [15].

The values were expressed as mean \pm SEM. The data were analysed by using GraphPad Prism software version 5.03. The results were compared by using the ANOVA-One-Way test followed by Mann-Whitney $U$ test. The difference was considered statistically significant at $p<0.05$. The value of the integrated glycemic index of the area under glycemic curve $\left(\mathrm{AUC}_{\mathrm{glu}}, \mathrm{mmol} / \mathrm{L} \mathrm{min}\right)$ was calculated using the statistical software package "MedCalk, v.9.3.7.0".

\section{RESULTS AND DISCUSSION}

At the first stage of the screening study, the effect of the herbal mixtures and the comparison drugs on basal glycemia and on glycemia after carbohydrate loading by OGTT after 20 days of preventive treatment was studied. This test allows simulate alimentary hyperglycemia that occurs after eating. Hypoglycemic activity of the herbal mixtures and reference drugs was manifested by their ability to reduce blood glucose levels at the 30th minute of the test, during its maximum increase in response to oral carbohydrate load (Tab. 2).

The results of the study showed that 20-day preventive treatment by all five herbal mixtures at doses $6 \mathrm{~mL} / \mathrm{kg} /$ day, $9 \mathrm{~mL} / \mathrm{kg} /$ day and $12 \mathrm{~mL} / \mathrm{kg} /$ day significantly $(p<0.05)$ was reduced glycemia at the 30th minute of OGTT compared with the control group. However, the best results 


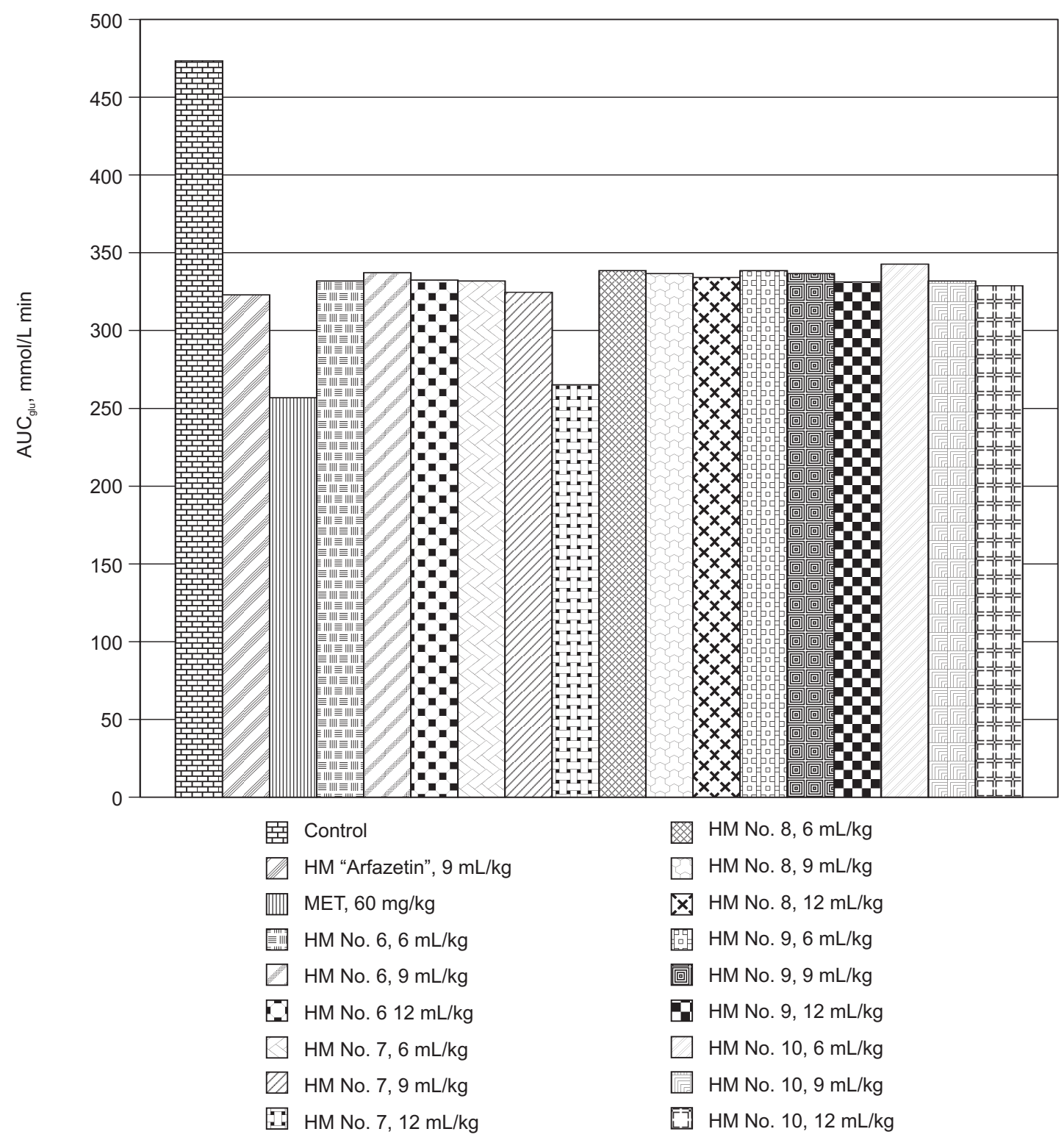

Fig. Hypoglycemic effect of the herbal mixtures compared to the official herbal mixture "Arfazetin" and tablets metformin by OGTT after 20 days of preventive treatment of normoglycemic rats, mean \pm SEM, $n=8$.

of hypoglycemic activity at the 30th minute of the test showed the herbal mixture No. 7 at dose $12 \mathrm{~mL} / \mathrm{kg} / \mathrm{day}$, it reduced blood glucose levels by $44 \%$, relative to the control group. Tablets metformin showed a similar result in efficacy, as they reduced alimentary hyperglycemia by $46 \%$ relative to the control group of animals at 30th minute. The official herbal mixtures "Arfazetin" was inferior in efficiency to the herbal mixture No. 7 at dose $12 \mathrm{~mL} / \mathrm{kg} /$ day and reduced glycemia by $32 \%$ relative to the control group at the 30th minute of the test (Fig.).

During the determination of integrated glycemic index based on the results of OGTT, it was found that the area under glycemic curve $\left(\mathrm{AUC}_{\mathrm{glu}}\right)$ in the herbal mixture No. 7 (12 mL/kg/day) was $265.2 \mathrm{mmol} / \mathrm{L}$ min. Regarding the results of the comparison drugs, the $\mathrm{AUC}_{\mathrm{glu}}$ of metformin ( $60 \mathrm{mg} / \mathrm{kg} /$ day) was lower and amounted to $256.8 \mathrm{mmol} / \mathrm{L}$ min, and the herbal mixture "Arfezetin" ( $9 \mathrm{~mL} / \mathrm{kg} /$ day) was higher and amounted to $322.8 \mathrm{mmol} / \mathrm{L} \mathrm{min}$.

In the second stage of the screening study, the ability of the herbal mixtures No. 6-10 and comparison drugs to improve carbohydrate tolerance was determined using IPGTT. The hypoglycemic effect of the herbal mixtures and comparison drugs was assessed by their ability to reduce hyperglycemia at 15 th minute of IPGTT during the maximum rise of blood glucose in the animals in response to intraperitoneal carbohydrate load.

During the study, a significant $(p<0.05)$ increase in blood glucose levels was observed in animals from the control group at the 15th minute of the test (peak hyperglycemic), exceeding the initial data by 2.0 times. The best ability to reduce the hyperglycemic peak of IPGTT showed the herbal mixture No. 7 (12 mL/kg/day) because 


\section{HYPOGLYCEMIC EFFECT OF THE HERBAL MIXTURES COMPARED TO THE OFFICIAL HERBAL MIXTURE “ARFAZETIN” AND TABLETS METFORMIN BY IPGTT AFTER 20 DAYS OF PREVENTIVE TREATMENT OF NORMOGLYCEMIC RATS}

\begin{tabular}{|c|c|c|c|c|}
\hline \multirow{2}{*}{ Group of animals } & \multicolumn{4}{|c|}{ Glucose level, $\mathrm{mmol} / \mathrm{L}$} \\
\hline & $0 \mathrm{~min}$ & $15 \mathrm{~min}$ & $45 \mathrm{~min}$ & $60 \mathrm{~min}$ \\
\hline \multicolumn{5}{|c|}{ Series second } \\
\hline Control & $4.21 \pm 0.11$ & $8.62 \pm 0.17^{*}$ & $5.23 \pm 0.18$ & $4.42 \pm 0.11$ \\
\hline HM “Arfazetin”, 9 mL/kg & $4.19 \pm 0.18$ & $6.82 \pm 0.19^{*}$ & $5.01 \pm 0.17$ & $4.43 \pm 0.15$ \\
\hline MET, $60 \mathrm{mg} / \mathrm{kg}$ & $4.14 \pm 0.19$ & $6.32 \pm 0.17 * / * *$ & $4.92 \pm 0.18$ & $4.21 \pm 0.13$ \\
\hline HM No. $6,6 \mathrm{~mL} / \mathrm{kg}$ & $4.18 \pm 0.19$ & $7.47 \pm 0.16^{*}$ & $5.48 \pm 0.16$ & $4.32 \pm 0.18$ \\
\hline HM No. $6,9 \mathrm{~mL} / \mathrm{kg}$ & $4.09 \pm 0.15$ & $7.37 \pm 0.13^{*}$ & $5.31 \pm 0.18$ & $4.18 \pm 0.16$ \\
\hline HM No. $612 \mathrm{~mL} / \mathrm{kg}$ & $4.17 \pm 0.16$ & $7.16 \pm 0.14^{*}$ & $5.11 \pm 0.17$ & $4.28 \pm 0.18$ \\
\hline HM No. 7, $6 \mathrm{~mL} / \mathrm{kg}$ & $4.09 \pm 0.17$ & $7.19 \pm 0.17^{*}$ & $5.26 \pm 0.18$ & $4.17 \pm 0.17$ \\
\hline HM No. 7, $9 \mathrm{~mL} / \mathrm{kg}$ & $4.11 \pm 0.18$ & $7.07 \pm 0.16^{*}$ & $5.11 \pm 0.16$ & $4.20 \pm 0.13$ \\
\hline HM No. 7, $12 \mathrm{~mL} / \mathrm{kg}$ & $4.15 \pm 0.21$ & $6.36 \pm 0.17 * / * *$ & $4.94 \pm 0.16^{*}$ & $4.21 \pm 0.16$ \\
\hline HM No. $8,6 \mathrm{~mL} / \mathrm{kg}$ & $4.16 \pm 0.17$ & $7.38 \pm 0.17^{*}$ & $5.39 \pm 0.15$ & $4.27 \pm 0.18$ \\
\hline HM No. $8,9 \mathrm{~mL} / \mathrm{kg}$ & $4.22 \pm 0.14$ & $7.27 \pm 0.11^{*}$ & $5.22 \pm 0.14$ & $4.31 \pm 0.18$ \\
\hline HM No. $8,12 \mathrm{~mL} / \mathrm{kg}$ & $4.09 \pm 0.17$ & $7.19 \pm 0.17^{*}$ & $5.28 \pm 0.17$ & $4.22 \pm 0.19$ \\
\hline HM No. 9, $6 \mathrm{~mL} / \mathrm{kg}$ & $4.18 \pm 0.16$ & $7.32 \pm 0.17^{*}$ & $5.25 \pm 0.18$ & $4.29 \pm 0.14$ \\
\hline HM No. 9, $9 \mathrm{~mL} / \mathrm{kg}$ & $4.14 \pm 0.17$ & $7.29 \pm 0.16^{*}$ & $5.11 \pm 0.16$ & $4.29 \pm 0.19$ \\
\hline HM No. $9,12 \mathrm{~mL} / \mathrm{kg}$ & $4.17 \pm 0.13$ & $7.11 \pm 0.18^{*}$ & $5.08 \pm 0.17$ & $4.26 \pm 0.17$ \\
\hline HM No. $10,6 \mathrm{~mL} / \mathrm{kg}$ & $4.31 \pm 0.25$ & $7.49 \pm 0.17^{*}$ & $5.29 \pm 0.22$ & $4.43 \pm 0.18$ \\
\hline HM No. $10,9 \mathrm{~mL} / \mathrm{kg}$ & $4.12 \pm 0.17$ & $7.31 \pm 0.17 *$ & $5.18 \pm 0.16$ & $4.27 \pm 0.16$ \\
\hline HM No. $10,12 \mathrm{~mL} / \mathrm{kg}$ & $4.28 \pm 0.17$ & $7.21 \pm 0.18^{*}$ & $5.03 \pm 0.18$ & $4.32 \pm 0.18$ \\
\hline
\end{tabular}

Notes: Values are expressed as mean \pm SEM from 8 rats; $*<<0.05$ with respect to Control group; ${ }^{* *}$ $p<0.05$ with respect to the herbal mixture "Arfazetin"

blood glucose level was lower by $26 \%$ relative to the control group. Tablets metformin showed a similar effect and reduced hyperglycemia at the 15 th minute of the test by $27 \%$ relative to the control group, and the official herbal mixture "Arfazetin" was slightly inferior to the effectiveness of the herbal mixture No. 7 at dose $12 \mathrm{~mL} / \mathrm{kg} /$ day and reduced hyperglycemia by $21 \%$. By the end of the experiment at the 60th minute of IPGTT, the blood glucose level returned to baseline in all groups (Tab. 3 ).

The results of a screening study using OGTT and IPGTT of the herbal mixtures No. 6-10, which are used in folk medicine for the prevention and treatment of diabetes mellitus type 2, indicate dose-dependent hypoglycemic activity. The best hypoglycemic effect of the studied objects was shown at a dose $12 \mathrm{~mL} / \mathrm{kg}$ /day.

The study using glucose load tests showed that the herbal mixtures No. 6, No. 8, No. 9 and No. 10 at doses $6 \mathrm{~mL} / \mathrm{kg} /$ day, $9 \mathrm{~mL} / \mathrm{kg} /$ day and $12 \mathrm{~mL} / \mathrm{kg} /$ day showed hypoglycemic activity, but it is slightly lower compared to the herbal mixture No. 7 (12 mL/kg/day) and comparison drugs the official herbal mixture "Arfazetin" ( $9 \mathrm{~mL} / \mathrm{kg} /$ day) and tablets metformin (60 mg/kg/day) (Tab. 2, 3).

Hypoglycemic activity of the studied herbal mixtures is quite predictable, because they include medicinal plant raw materials containing biologically active substances with proven hypoglycemic action. The main groups of biologically active substances that can lower blood glu- cose are polysaccharides, especially inulin that has the ability to increase glucagon-like peptide-1 (GLP-1), which increases insulin secretion, inhibits glucagon secretion, causes proliferation and neogenesis of $\beta$-cells and increases the response of $\beta$-cells to glucose $[16,17]$. Presented herbal mixtures contain herbal raw materials that are rich in carbohydrates, such as Cichorii radices (the herbal mixtures No. 6, No. 8 and No. 9), Taraxaci radices (the herbal mixture No. 7), Elymi repens rhizomata (the herbal mixtures No. 6, No. 8 and No. 10), Inulae rhizomata et radices (the herbal mixture No. 7), Helianthi tuberosi tuber (the herbal mixture No.10), Polemonii rhizomata cum radicibus (the herbal mixtures No. 9 and No. 10), Avenae sativae semina (the herbal mixture No. 6).

In addition, medicinal plants that are part of the studied herbal mixtures contain polyphenolic compounds that exhibit antidiabetic activity by different mechanism of actions, including stimulation of insulin secretion, improvement of pancreatic $\beta$-cell functionality, inhibition of gluconeogenesis, intensification of glucose uptake, delay of carbohydrate digestion and glucose absorption, inhibition of protein glycation and insulin fibrillation $[18,19,20]$. No less important is their antioxidant activity in the treatment and prevention of diabetes and its complications, because they can include suppression of reactive oxygen spesies (ROS) formation either by inhibition of enzymes or by chelating trace elements involved in free radical 
generation; scavenging ROS; inhibition the enzymes involved in ROS generation - microsomal monooxygenase, glutathione S-transferase, mitochondrial succinoxidase, nicotinamide adenine dinucleotide phosphate (NADH) oxidase, and so forth [20,21, 22]. Medicinal plant raw materials containing phenolic compounds are Pulmonaria radices (the herbal mixture No. 6), Helichrysi arenarii flores (the herbal mixture No. 7), Origani herba (the herbal mixture No. 7), Menthae folia (the herbal mixture No. 10), Melissae folia (the herbal mixture No. 9), Leonuri herba (the herbal mixture No. 8), Urticea folia (the herbal mixture No. 9), Rosae fructus (the herbal mixtures No. 6, No. 7, No. 8 and No. 10), Medicago herba (the herbal mixture No. 5), Crataegi fructus (the herbal mixtures No. 8, No. 9 and No. 10), Maydis style cum sigmatis (the herbal mixture No. 7), Sophorae japonicae fructus (the herbal mixture No. 9).

Thus, screening study of the herbal mixtures No. 6-10 shows their hypoglycemic activity by OGTT, IPGTT and confirms the effectiveness of their use in folk medicine for the prevention and treatment of diabetes mellitus type 2 .

\section{CONCLUSIONS}

1. For the first time, it was conducted the screening study of hypoglycemic activity of the herbal mixtures No. 6-10, which are used in folk medicine for the prevention and treatment of diabetes mellitus type 2 .

2. It was determined that the greatest effectiveness in terms of the ability to reduce alimentary hyperglycemia during OGTT and reduce impaired carbohydrate tolerance during IPGTT show the herbal mixture No. 7, which includes Inulae rhizomata et radices, Helichrysi arenarii flores, Maydis style cum sigmatis, Origani herba, Rosae fructus, Taraxaci radices. It was established their conditional therapeutic dose $12 \mathrm{~mL} / \mathrm{kg} /$ day.

Conflict of interests: authors have no conflict of interest to declare.

\section{REFERENCES}

1. Standards of medical care in diabetes / American Diabetes Association. Diabetes care. 2020. № 43. (1). 224 c. URL: https://care.diabetesjournals org/content/diacare/suppl/2019/12/20/43.Supplement_1.DC1/Standards_of_Care_2020.pdf (Date of access: 20.07.2020).

2. IDF Diabetes Atlas / International Diabetes Federation. 9th ed. Brussels, 2019. URL: https://www.diabetesatlas.org (Date of access: 20.07.2020).

3. Differentiation of diabetes by pathophysiology, natural history, and prognosis / J. S. Skyler et al. Diabetes. 2017. № 66 (2). P. 241-255. DOI: https:// doi.org/10.2337/db16-0806 (Date of access: 20.07.2020).

4. Predictive models of diabetes complications: protocol for a scoping review / R. Ndjaboue et al. Systematic reviews. 2020 . № 9 (1). P. 137. DOI: https://doi.org/10.1186/s13643-020-01391-w (Date of access: 20.07.2020).

5. Natural phyto-bioactive compounds for the treatment of type 2 diabetes: inflammation as a target / S. Gothai et al. Nutrients. 2016 . № 8 (8). P. 461. DOI: https://doi.org/10.3390/nu8080461 (Date of access: 20.07.2020).

6. Phytotherapy in the management of diabetes: a review / P. Governa et al. Molecules. 2018. № 23 (1). P. 105. DOI: https://doi.org/10.3390/ molecules23010105 (Date of access: 20.07.2020).

7. The role of medicinal plants in the treatment of diabetes: a systematic review / W. Kooti et al. Electronic physician. 2016. № 8 (1). P. 1832-1842. DOI: https://doi.org/10.19082/1832 (Date of access: 20.07.2020)

8. Основні принципи використання лікарських рослин та їх зборів для ліування та профілактики цукрового діабету 2 типу : огляд літ. / А. О. Савич та ін. Фітотерапія часопис. 2019. № 4. С. 43-46. DOI: https://doi.org/10.33617/2522-9680-2019-4-43 (дата звернення: 20.07.2020)

9. Antihyperglycemic, hypolipidemic and antioxidant properties of the herbal mixtures in dexamethasone-induced insulin resistant rats / A. Savych et al. PharmacologyOnline. 2020. № 2. P. 73-82.

10. Товстуха Є. С. Золоті рецепти української народної медицини. Київ : Країна Мрій, 2010. 550 с.

11. WHO Guidelines on good agricultural and mixture practices (GACP) for medicinal plants / World Health Organization. Geneva, 2003. 72 p. URL: https://apps.who.int/iris/bitstream/handle/10665/42783/9241546271.pdf?sequence=1 (Date of access: 20.07.2020)

12. Council directive $2010 / 63 / \mathrm{EU}$, of the $22^{\text {nd }}$ September 2010 on the approximation of laws, regulations and administrative provisions of the member states regarding the protection of animals used for experimental and other scientific purposes. Offical Journal of the European Communities. 2010. Vol. 53. P. 33. DOI: https://doi.org/10.3000/17252555.L_2010.276.eng (Date of access: 20.07.2020).

13. Savych A., Marchyshyn S. Investigation of pharmacological activity the new antidiabetic plant gathering in streptozotocin-nicotinamide-induced diabetes in the rats. The Pharma Innovation Journal. 2017. № 6 (3). P. 175-177. URL: http://www.thepharmajournal.com/archives/?year=2017\&vol= 6\&issue $=3 \&$ ArticleId=995 (Date of access: 20.07 .2020 ).

14. Metformin acutely lowers blood glucose levels by inhibition of intestinal glucose transport / O. Horakova. et al. Scientific Reports. 2019. № 9 . P. 6156. URL: https://www.nature.com/articles/s41598-019-42531-0 (Date of access: 20.07.2020)

15. Доклінічні дослідження лікарських засобів : метод. рек. / за ред. чл.-кор. АМН України О. В. Стефанова. Київ : Авіценна, 2001. 528 с

16. Phytosterols and inulin-enriched soymilk increases glucagon-like peptide-1 secretion in healthy men: double-blind randomized controlled trial, subgroup study / N. Kietsiriroje et al. BMC research notes. 2018. № 11 (1). P. 844. DOI: https://doi.org/10.1186/s13104-018-3958-5 (Date of access: 20.07.2020).

17. Paternoster S., Falasca M. Dissecting the physiology and pathophysiology of glucagon-like peptide-1. Frontiers in Endocrinology. 2018. № 9. P. 584. DOI: https://doi.org/10.3389/fendo.2018.00584 (Date of access: 20.07.2020).

18. Dietary polyphenols and gene expression in molecular pathways associated with type 2 diabetes mellitus: A Review / G. G. Kang et al. International Journal of Molecular Sciences. 2019. № 21 (1). P. 140. DOI: https://doi.org/10.3390/ijms21010140 (Date of access: 20.07.2020).

19. Adisakwattana S. Cinnamic acid and its derivatives: mechanisms for prevention and management of diabetes and its complications. Nutrients. 2017. № 9 (2). P. 163. DOI: https://doi.org/10.3390/nu9020163 (Date of access: 20.07.2020).

20. Antioxidant and antidiabetic effects of flavonoids: a structure-activity relationship based study / M. N. Sarian et al. BioMed research international. 2017. DOI: https://doi.org/10.1155/2017/8386065 (Date of access: 20.07.2020).

21. Panche A. N., Diwan A. D., Chandra S. R. Flavonoids: an overview. Journal of nutritional science. 2016. DOI: https://doi.org/10.1017/jns.2016.41 (Date of access: 20.07.2020)

22. Kaurinovic B., Vastag G. Flavonoids and phenolic acids as potential natural antioxidants. IntechOpen. 2019. DOI: https://doi.org/10.5772/intechopen.83731 (Date of access: 20.07.2020). 


\section{REFERENCES}

1. American Diabetes Association. (2020). Standards of medical care in diabetes. Diabetes care, 43, 1212. Available at: https://care.diabetesjournals. org/content/diacare/suppl/2019/12/20/43.Supplement_1.DC1/Standards_of_Care_2020.pdf.

2. International Diabetes Federation. (2019). IDF Diabetes Atlas. 9th ed. Brussels, Available at: https://www.diabetesatlas.org.

3. Skyler, J. S., Bakris, G. L., Bonifacio, E., Darsow, T., Eckel, R. H., Groop, L. et al. (2017). Differentiation of diabetes by pathophysiology, natural history, and prognosis. Diabetes, 66 (2), 241-255. doi: https://doi.org/10.2337/db16-0806.

4. Ndjaboue, R., Farhat, I., Ferlatte, C. A., Ngueta, G., Guay, D., Delorme, S. et al. (2020). Predictive models of diabetes complications: protocol for a scoping review. Systematic reviews, 9 (1), 137. doi: https://doi.org/10.1186/s13643-020-01391-w.

5. Gothai, S., Ganesan, P., Park, S., Fakurazi, S., Choi, D., Arulselvan, P. (2016). Natural phyto-bioactive compounds for the treatment of type 2 diabetes: inflammation as a target. Nutrients, 8 (8), 461. doi: https://doi.org/10.3390/nu8080461.

6. Governa, P., Baini, G., Borgonetti, V., Cettolin, G., Giachetti, D., Magnano, A. R., et al. (2018) Phytotherapy in the management of diabetes: a review. Molecules, 23 (1), 105. doi: https://doi.org/10.3390/molecules23010105.

7. Kooti, W., Farokhipour, M., Asadzadeh, Z., Ashtary-Larky, D., Asadi-Samani, M. (2016). The role of medicinal plants in the treatment of diabetes: a systematic review. Electronic physician, 8 (1), 1832-1842. doi: https://doi.org/10.19082/1832.

8. Savych, A. O., Marchyshyn, S. M., Kozyr, H. R., Skrinchuk, O. Y. (2019). Osnovni pryntsypy vykorystannya likarskykh roslyn ta yikh zboriv dlya likuvannya ta profilaktyky tsukrovoho diabetu 2 typu. Journal Phypotherapy, 4, 43-46. doi: https://doi.org/10.33617/2522-9680-2019-4-43.

9. Savych, A., Marchyshyn, S., Basaraba, R., Lukanyuk, M. (2020). Antihyperglycemic, hypolipidemic and antioxidant properties of the herbal mixtures in dexamethasone-induced insulin resistant rats. PharmacologyOnLine, 2, 73-82.

10. Tovstuha, Ye. S. (2010). Zoloti retsepty ukrayinskoyi narodnoyi medytsyny. Kyiv: Kraina Mriy Publishers, 550.

11. World Health Organization. (2003). WHO Guidelines on good agricultural and mixture practices (GACP) for medicinal plants. Geneva, Switzerland, 72.

12. EEC. (2010)."Council directive 2010/63/EU, of the $22^{\text {nd }}$ September 2010 on the approximation of laws, regulations and administrative provisions of the member states regarding the protection of animals used for experimental and other scientific purposes". Offical Journal of the European Communities, 1-29.

13. Savych, A., Marchyshyn, S. (2017). Investigation of pharmacological activity the new antidiabetic plant gathering in streptozotocin-nicotinamideinduced diabetes in the rats. The Pharma Innovation Journal, 6 (3), 175-177.

14. Horakova, O., Kroupova, P., Bardova, K., Janovska, P., Kopecky J. et al. (2019). Metformin acutely lowers blood glucose levels by inhibition of intestinal glucose transport. Scientific Reports, 9, 6156. doi: https://doi.org/10.1038/s41598-019-42531-0.

15. Stefanov, O. V. (2001). Doklinichni doslidzhennya likarskykh zasobiv: Metodychni rekomendatsiyi. Kyiv: Avitsena Publishers, 528

16. Kietsiriroje, N., Kanjanahirun, K., Kwankaew, J., Ponrak, R., Soonthornpun, S. (2018). Phytosterols and inulin-enriched soymilk increases glucagonlike peptide-1 secretion in healthy men: double-blind randomized controlled trial, subgroup study. BMC research notes, 11 (1), 844 . doi: https:// doi.org/10.1186/s13104-018-3958-5

17. Paternoster, S., Falasca, M. (2018). Dissecting the physiology and pathophysiology of glucagon-like peptide-1. Frontiers in Endocrinology, 9, 584. doi: https://doi.org/10.3389/fendo.2018.00584.

18. Kang, G. G., Francis, N., Hill, R., Waters, D., Blanchard, C., Santhakumar, A. B. (2019). Dietary polyphenols and gene expression in molecular pathways associated with type 2 diabetes mellitus: A Review. International Journal of Molecular Sciences, 21 (1), 140. doi: https://doi.org/10.3390/ ijms21010140.

19. Adisakwattana, S. (2017). Cinnamic acid and its derivatives: mechanisms for prevention and management of diabetes and its complications Nutrients, 9 (2), 163. doi: https://doi.org/10.3390/nu9020163.

20. Sarian, M. N., Ahmed, Q. U., Mat So'ad, S. Z., Alhassan, A. M., Murugesu, S., Perumal, V., et al. (2017). Antioxidant and antidiabetic effects of flavonoids: a structure-activity relationship based study. BioMed research international, 2017, 8386065. doi: https://doi.org/10.1155/2017/8386065

21. Panche, A. N., Diwan, A. D., Chandra, S. R. (2016). Flavonoids: an overview. Journal of nutritional science, 5, e47. doi: https://doi.org/10.1017/ jns.2016.41.

22. Kaurinovic, B., Vastag, G. (2019). Flavonoids and phenolic acids as potential natural antioxidants, Antioxidants, Emad Shalaby, IntechOpen doi: https://doi.org/10.5772/intechopen.83731.

\section{Information about authors:}

Savych A., PhD in Pharmacy, Assistant of the Department of Pharnacognosy with Medical Botany, I. Horbachevsky Ternopil National Medical University. E-mail alonasavych@gmail.com. ORCID: https://orcid.org/0000-0001-6053-7625

Marchyshyn S., Doctor of Pharmacy, Professor, Head of the Department of Pharnacognosy with Medical Botany, I. Horbachevsky Ternopil National Medical University. E-mail: svitlanafarm@ukr.net. ORCID: https://orcid.org/0000-0001-9585-1251

Doroshenko O., PhD in Pharmacy, Assistant of the Department of Pharmacology with Internal Medicine No. 3 named after Berezhnytsky N. M., Ivano-Frankivsk National Medical University. E-mail: cito.9876@gmail.com. ORCID: https://orcid.org/0000-0003-4861-2025 Відомості про авторів:

Савич А. О., кандидатка фармац. наук, асистентка кафедри фармакогнозії з медичною ботанікою,

Тернопільський національний медичний університет імені I. Я. Горбачевського МОз України. E-mail: alonasavych@gmail.com. ORCID: https://orcid.org/0000-0001-6053-7625

Марчишин С. М., докторка фармац. наук, професорка, завідувачка кафедри фармакогнозії з медичною ботанікою,

Тернопільський національний медичний університет імені I. Я. Горбачевського МОЗ України. E-mail: svitlanafarm@ukr.net. ORCID: https://orcid.org/0000-0001-9585-1251

Дорошенко О. Г., кандидатка фармац. наук, асистентка кафедри фармакології з внутрішньої медицини № 3 імені Бережницького Н. М., Івано-Франківський національний медичний університет. E-mail: cito.9876@gmail.com. ORCID: https://orcid.org/0000-0003-4861-2025 Сведения об авторах:

Савич А. А., кандидат фармац. наук, ассистент кафедры фармакогнозии с медицинской ботаникой, Тернопольский национальный медицинский университет имени И. Я. Горбачевского МЗ Украины. E-mail: alonasavych@gmail.com.

ORCID: https://orcid.org/0000-0001-6053-7625

Марчишин С. М., доктор фармац. наук, профессор, заведующая кафедрой фармакогнозии с медицинской ботаникой,

Тернопольский национальный медицинский университет имени И. Я. Горбачевского МЗ Украины. E-mail: svitlanafarm@ukr.net.

ORCID: https://orcid.org/0000-0001-9585-1251

Дорошенко О. Г., кандидат фармац. наук, ассистент кафедры фармакологии с внутренней медициной № 3 имени Бережницкого Н. М.,

Ивано-Франковский национальный медицинский университет. E-mail: cito.9876@gmail.com. ORCID: https://orcid.org/0000-0003-4861-2025

Надійшла до редакції 21.08.2020 p. 